\title{
Issues in Professional Practice and Their Implementation in Engineering Curricula
}

\author{
Samuel P. Clemence, Daniel J. McGinley \\ Syracuse University/Institute for Professional Practice
}

A successful career in engineering is dependant not only on the engineer's technical expertise, experience, and ability to solve problems, it is also imperative to have the acumen to foresee and manage many of the nontechnical issues which are integral to the successful management of any project. Until recently, most engineering students and young practicing engineers have not been formally exposed to these issues.

In the proposed Engineering Criteria $2000^{1}$ that has been developed by the Accreditation Board for Engineering and Technology (ABET) it clearly states (Criterion 3. Program Outcomes and Assessment) "Engineering programs must demonstrate that their graduates have...(f) an understanding of professional and ethical responsibility." This requirement, coupled with specific proposed Program Criteria ${ }^{2}$ (e.g. Civil Engineering, Architectural Engineering) stating "Graduates of the program must demonstrate an understanding of professional practice issues" warrants proven methods for delivering professional practice and ethics education.

The Institute for Professional Practice (IPP) has developed an innovative approach to include these important subjects in the engineering curriculum. This paper will describe several ways of implementing issues in profesional practice either through the ABET-required major design experience or as separate elective courses.

\section{Background of the Institute}

The Institute for Professional Practice was originated in 1989 by ASFE - Professional Firms Practicing in the Geosciences (originally the Association of Soil and Foundation Engineers) with funds derived from an international conference held in San Francisco a few years previously. While this geotechnical engineering group provided the impetus for establishing the Institute, it was set up as a separate, non-profit 501(c)(3) corporation to serve the entire spectrum of engineering practice in the United States.

To date, virtually all of the Institute's funding has been derived from returns on the invested original capital, donations from ASFE, Terra Insurance Company, the DPIC Companies, and pledges and contributions from individuals and firms in the national consulting engineering community who constitute the founding members of IPP's Heritage Society. The purpose of the Heritage Society is to encourage financial support for the Institute and to recognize those who have made a commitment to the Institute. 


\section{$\underline{\text { The IPP Mission }}$}

Stated in general terms, the Institute for Profesional Practice is dedicated to providing programs to assist engineering and science students and graduates in making the transition from academia to a career in professional practice. Institute programs address those issues which make a definitive difference between true success and failure in an engineered project.

\section{$\underline{\text { Issues in Professional Engineering Practice Program }}$}

In 1992 in response to the concerns voiced by the practicing engineering community, the General Electric Fund and the Institute for Professional Practice sponsored the development of a course called Issues in Professional Engineering Practice. The intent of the course is to draw upon practicing engineers and allied professionals to assist engineering schools in raising the level of student awareness regarding potentially disruptive non-technical issues in professional engineering practice. The material is also being used as an in-house training module by engineering firms to create an awareness of these critical issues among their young engineering staff. It was developed for IPP by Dr. Ronald E. Bucknam, who retired in 1990 from full-time consulting practice after almost 30 years as a practicing engineer and president of a consulting firm. He is now on the faculty of the University of Washington. The topics covered are based on his vast experience as well as the comments and contributions of more than 30 engineers and allied professionals around the country.

The course material is organized to parallel the progress of a project through a design firm or agency. The spectrum of topics includes discussions on types of engineering organizations and the basics of income, expenses and profit; marketing professional services to public and private entities; the Quality Based Selection (QBS) process; preparation of proposals, and types of contracts for professional services. The subjects then move into the basics of project management, including allocation of responsibility and authority; labor utilization; establishing budget or profitability goals; team building through motivation and leadership; monitoring and controlling project progress; application of TQM concepts; value engineering and client followup. Also included are sections on professionalism and the responsibility of the engineer to society, as well as discussions of engineering ethics applied to common day-to-day incidents likely to be encountered in practice. These issues are presented in the form of actual case histories (fictionalized to preserve the identities of those involved), based on the experiences of a number of engineers nationally.

The final segment of the course focuses on retaining a reasonable profit, or avoiding losses. Emphasis is placed on effective communications among team members, as well as with clients and the community. Topics include coping with project overruns; collecting accounts receivable; engineering contract language, clauses and pitfalls; professional liability insurance; limitation of liability and other loss prevention techniques; dispute resolution methods and the climate, process and cost of being sued. 
In addition to the lecture notes, a boxed set of reference materials, euphemistically called a "course-in-a-box", has been assembled for schools and firms wishing to implement an in-house training program. The contents of the present "course-in-a-box" consist of the following:

- Bachner, John Philip (1991). Practice Management for Design Professionals, John Wiley \& Sons

- Culp Gordon and R. Anne Smith (1992), Managing People (Including Yourself) for Project Success, van Nostrand Reinhold

- Johnson, Deborah G. (1991), Ethical Issues in Engineering, Prentice Hall

- ASFE loss prevention audio tape series (1 - 18)

- The Real World of Engineering: Case Histories 1 - 64, ASFE

- ASFE Loss Prevention Test Kit

- Contract Reference Guide, ASFE

- Standard Form: Subcontract Agreement for Drilling Services, ASFE

- Standard Form: Agreement for Subcontract Laboratory Services, ASFE

- Standard Form of Agreement for Preliminary Site Assessment Services, ASFE

- Terms for Geotechnical Engineering Services, ASFE

The Issues in Professional Engineering Practice course materials have been requested by 128 practicing engineers and 321 faculty in 252 engineering programs in the United States (as well as 16 programs in ten foreign countries). In addition, 184 sets of the "course-in-a-box" reference library have been provided to faculty in these engineer programs. The course has been implemented in part or whole by 178 engineering programs in this country. Of these, 48 programs are offering a full Issues course, and 35 of this group are having the course taught entirely by practicing engineers.

\section{Schools Offering Full Course Using IPEP Materials}

$\begin{array}{ll}\text { AL06 } & \text { Alabama A\&M University } \\ \text { CA02 } & \text { Cal Poly - SLO } \\ \text { CA03 } & \text { Cal Poly -Pomona } \\ \text { CA04 } & \text { Cal State U at Chico* } \\ \text { CA05 } & \text { Cal State U at Fresno } \\ \text { CA07 } & \text { Cal State U at Long Beach } \\ \text { CA18 } & \text { U of California - Berkeley } \\ \text { CO01 } & \text { Colorado State University } \\ \text { CT03 } & \text { University of New Haven } \\ \text { FL06 } & \text { University of Florida* } \\ \text { HI01 } & \text { Uof Hawaii at Manoa } \\ \text { IL03 } & \text { S. Illinois U at Carbondale } \\ \text { IN03 } & \text { Tri-State University } \\ \text { LA03 } & \text { McNeese State University } \\ \text { MA02 } & \text { Mass Inst of Tech } \\ \text { MA04 } & \text { U of Mass at Dartmouth } \\ \text { MA05 } & \text { Tufts University }\end{array}$

$\begin{array}{ll}\text { MA08 } & \text { Worcester Polytechnic Inst } \\ \text { ME01 } & \text { University of Maine } \\ \text { MI01 } & \text { Michigan State University } \\ \text { MI02 } & \text { Michigan Tech University } \\ \text { MI04 } & \text { University of Michigan } \\ \text { MI05 } & \text { Wayne State University } \\ \text { MO03 } & \text { U Missouri - Rolla } \\ \text { MT01 } & \text { Montana State University } \\ \text { NE01 } & \text { Uof Nebraska - Lincoln } \\ \text { NH02 } & \text { New England College } \\ \text { NH03 } & \text { U of New Hampshire } \\ \text { NJ01 } & \text { New Jersey Inst of Tech } \\ \text { NJ03 } & \text { Rutgers University } \\ \text { NV01 } & \text { U of Nevada-Las Vegas } \\ \text { OR01 } & \text { Oregon State University } \\ \text { OR02 } & \text { Portland State University } \\ \text { PA09 } & \text { University of Pittsburgh* }\end{array}$

RI03 Roger Williams University

TN04 University of Memphis

TN04 Tennessee Tech Univ

TN05 University of Tennessee

TN06 Vanderbilt University

TX01 Lamar University

UT01 Brigham Young University

VA03 Virginia Military Institute

VA05 Virginia Western CC

VT01 Norwich University

WA04 University of Washington

* Multiple programs

Total programs $=48 ;$ full $=35$

Source: R.E.Bucknam October 31, 1996 


\section{$\underline{\text { University/Liaison Network Program }}$}

The Summary Report of the 1995 Civil Engineering Education Conference ${ }^{3}$ identified four primary action areas: Faculty Development, Integrated Curriculum, Practitioner Involvement and Professional Degree. The use of IPP programs and materials is specifically suggested in the "recommended actions" section of the Integrated Curriculum and Practitioner Involvement areas.

In a recent national survey of engineering department heads and faculty using the Issues course program materials, $84 \%$ indicated their desire to have practitioners lecture to students about the non-technical issues encountered in professional engineering practice. In fact, many of the practicing engineers who are making presentations in engineering classrooms are members of IPP's University/Liaison Practitioner Network, a group of more than 164 practicing engineers and allied professionals who have volunteered to talk to engineering students around the country about the non-technical issues covered in the Issues course program.

Speakers are obtained from direct volunteers, professionals known to engineering faculty and through practitioners coordinating full professional practice courses at a local university. In many schools the students have an opportunity to evaluate these guest speakers for their ability to present material in a practical, informative and stimulating manner. Those speakers failing to receive approval from the students are not invited back, and suitable replacements are chosen.

At the current rate of implementation, it is estimated more than 1,200 engineering students attended full professional practice issues courses during 1996, and an additional 2,000 to 2,500 students were exposed to a portion of these topics at other schools using substantial segments of the Issues materials.

\section{Applied Ethics in Engineering Practice Program}

A new instructional module entitled Applied Ethics in Engineering Practice is being developed to provide engineering students and young practicing engineers with an understanding of the factors impacting ethical decision making in engineering practice, an ability to discern right from wrong in cases of apparent ethical dilemma, and methods for making proper decisions and achieving ethical results in such situations. It is not the intent of the module to focus on more expansive ethical dilemmas, such as the O-ring problems on the Challenger, global warming or the problems created by the Love Canal. Rather, the emphasis is on the day-to-day, sometimes stomach-wrenching issues most often confronting engineers in industry, private practice and government.

It is anticipated that this new course module will be ready for distribution by the Fall Semester of 1997. Also to be developed is a small reference library listing of materials to assist in presenting the course as an in-house training program or in a classroom setting. This set of materials, to include texts, references, video tapes, copies of televised commentary programs and other materials, is dubbed "ethics-in-a-box". 
The development of the applied ethics module is overseen in part by a non-convening board of comment and review, consisting of over fifty active and retired professional engineers in private and public practice, engineering faculty, deans, retired business persons, clergy, philosophy professors, physicians, lawyers, and a judge.

\section{Applied Ethics in Engineering Practice Seminars}

As a result of the work the Institute has been doing in connection with the development of the Applied Ethics module indicated above, several requests have been received to present seminar sessions ranging up to a half day in length focused on this topic. Seminars consisting of consideration of the factors influencing the day-to-day motivation of engineers and presenting guidelines for ethical behavior are supplemented with applications of the principles through indepth discussions of several "sanitized" case histories contributed by a number of practicing engineers across the country and taken from actual experience in engineering practice.

To date, seminars have been given by IPP Board members at Villanova University and the ACEC 1995 fall convention in Asheville, NC, while the Institute's past Executive Director, Ron Bucknam, has presented similar seminars at six other meetings.

Insofar as possible, these seminars are conducted on a break-even cost basis, with an honorarium sufficient to cover reimbursable expenses, if not the full time of the lecturers involved. The lead article in the March 1997 issue of the National Society of Professional Engineers' (NSPE) Engineering Times 4 "Is PE License a Boon to Ethics in Industry?" gives every indication that there is a trend toward more licensure and professionalism than in the past. Clifton Wright, chairman emeritus and director of the Houston-based A/E firm 3D/International attributes this to management's increased recognition of the need for engineers with high technical qualifications and ethical standards.

\section{Second Edition of Issues in Professional Engineering Practice Course}

Little is currently done to focus on the non-technical needs of the public works engineer in an increasingly complex society. This lack of communication and understanding of issues between engineers in the public and private sectors is one of the primary causes contributing to complicated consultant selection processes which often are not based on quality based selection (QBS) principles, include awkward contract requirements, and require time-consuming and convoluted review and permitting processes. All of these situations tend to create adversarial relations, escalated project overhead and expense, and greater potential for claims and litigation.

The second edition of the Issues in Professional Engineering Practice program will not only update several portions of the original course material, but will also focus on issues encountered in public works engineering with a goal of reaching the young public works engineer as well. A commitment has been obtained from members of the American Public Works Association (APWA) to assist in preparing this revision to focus on practicing public works engineers, and 
several engineers and attorneys in private practice throughout the United States have volunteered to review and update the existing course content.

Not only will the lecture notes be updated, it is also intended to distribute a new "course-in-abox" to augment the present reference collection, and to provide a wider selection of materials from among the engineering disciplines and closely allied professional groups. This presents an opportunity for professional organizations to contribute appropriate manuals, instructional tapes or other references. Both the revised lecture notes and augmented "course-in-a-box" are anticipated to be available for distribution during the 1997-98 school year.

\section{The Bridge Newsletter}

The Institute publishes a semi-annual newsletter called The Bridge, symbolic of IPP's mission of assisting in the transition from academia to the real world of professional practice. Each issue contains information about programs and projects under development, the people behind these succesful ventures, and opportunities to participate. The newsletter is now sent to approximately 1,700 engineers, educators and allied professionals nationally.

\section{Proposed Projects Under Development}

In addition to the basic on-going programs described above, the Institute is initiating involvement in the following projects to the extent described for each. It is intended that these projects be developed and supported on a stand-alone basis, with anticipated income from each sufficient to support its continuous improvement.

\section{A. Videotape Series on Applied Ethics in Engineering Practice}

A 15 to 20-minute dramatized videotape focused on a specific ethical dilemma often encountered in day-to-day engineering practice is being developed for use in the classroom or in-house training programs for the young (and perhaps not-so-young) practicing engineer. At present, a script has been written and approved, a production company selected and the Institute is working on the arrangements for marketing and distribution of the first in a potential series of presentations.

\section{B. Engineering Contracts CD ROM/Videotape Series}

Terra Insurance Company has developed a series of short educational presentations for the geotechnical engineering community dealing with common issues to be recognized and resolved in the preparation and acceptance of engineering design contracts. After the initial distribution of this series to Terra insureds, the Institute is preparing to refocus the series on an expanded 
engineering practice audience that will help the Institute to further its educational mission among students, faculty and the engineering community.

\section{Continuing Education Professional Practice Issue Modules}

Consideration is being given to the development of several education modules in formats suitable for home study or for in-house use by firms not located close to major population hubs where formal continuing education opportunities are available. Such a service will help satisfy the increasing requirements in many states for a prescribed number of continuing education units (CEUs) or professional development hours (PDHs) annually for renewal of the professional engineering license. Arrangements are in hand for granting continuing education units for the modules, once they are fully developed and implemented.

\section{$\underline{\text { Delivery }}$}

In order to bring such programs to fruition, much cooperation and support from national engineering organizations is required to develop, distribute, monitor and maintain the appropriate educational modules.

It is the policy of the institute to solicit the support of members of the national practicing engineering community and closely allied professionals to volunteer a small portion of their time to lecture at universities as part of the University/Liaison Practitioner Network, contribute case histories to augment the applied ethics course module, organize a group of practicing engineers to present an entire professional practice issues course at a local or regional engineering school, and participate in the Institute's on-going programs and special projects as a volunteer committee member or member of the Board of Directors. In order to expand this group as fully as practical, the Institute needs to be able to interact closely with professional societies and organizations so that its programs become recognized and committed individuals have the opportunity to gain personal satisfaction by becoming active participants.

\section{$\underline{\text { Summary }}$}

A fall 1995, conference of leaders of the American Consulting Engineers Council (ACEC) had as its theme the thought that the world is run by those who "show up." To guarantee engineers a place in running the world of the future, ACEC identified four areas where engineers need to demonstrate leadership: Imagination, Involvement, Information and Impact. The "Blue Ribbon Panel" report Seeing Into the Future 5 reconfirms that a successful career in engineering is dependant not only on the engineer's technical expertise, experience, and ability to solve problems, it is also imperative to have the acumen to foresee and manage many of the nontechnical issues which are integral to the successful management of any project.

IPP's innovative approach to include these important subjects in the engineering curriculum prepares engineers for their future. IPP programs address the proposed accreditation criteria 
from ABET, the education action plans of professional societies like NSPE and ASCE, and the "visioning" of ACEC. Being exposed to this information during the formative stage of an engineering career is undeniably necessary. Now is the time for engineering professionals to "plant trees under which they may never sit."

\section{Endnotes}

${ }^{1}$ ABET (1996), Engineering Criteria 2000, December 1995, Criteria for Accrediting Programs in Engineering in the United States approved for a two-year comment period beginning January 1996.

${ }^{2}$ ASCE (1996), PROPOSED Civil Engineering Program Criteria 2000, draft version submitted to ABET by the American Society of Civil Engineers dated October 12, 1996.

${ }^{3}$ ASCE (1996), 1995 Civil Engineering Education Conference, June 1996

${ }^{4}$ Kane, Elizabeth (1997), Is PE License a Boon to Ethics in the Industry? Engineering Times, NSPE, March 1997, p. 1.

${ }^{5}$ ACEC (1996), Seeing Into the Future subtitled The I Book: Results of Deliberations by ACEC's Blue Ribbon Panels Exploring the Four l's: Imagination, Involvement, Information and Impact, ACEC, 1996.

SAMUEL P. CLEMENCE, PE, Ph.D. has been awarded the Laura J. and Douglas Meredith Professorship for Teaching Excellence at Syracuse University, where he is a professor in the Department of Civil and Environmental Engineering and has been the senior associate dean of the L.C. Smith College of Engineering and Computer Science.

DANIEL J. McGINLEY is the Executive Director of the Institute for Professional Practice. He has nearly 20 years of engineering association management experience, most recently as the Education Activities Director for the American Society of Civil Engineers. He is the 1996 recipient of the George K. Wadlin Distinguished Service Award from the ASEE Civil Engineering Division and a graduate of NJIT. 